Article

\title{
Experimental Investigation of the Hydrate-Based Gas Separation of Synthetic Flue Gas with 5A Zeolite
}

\author{
Xiaoya Zang ${ }^{1,2,3,4}$, Na Zhang ${ }^{1}$, Xuebing Zhou ${ }^{1,2,3,4}$, Lihua Wan ${ }^{1,2,3,4}$ and Deqing Liang $1,2,3,4, *$ \\ 1 Guangzhou Institute of Energy Conversion, Guangzhou Center for Gas Hydrate Research, Chinese \\ Academy of Sciences, Guangzhou 510640, China; zangxy@ms.giec.ac.cn (X.Z.); \\ zhangna@ms.giec.ac.cn (N.Z.); zhouxb@ms.giec.ac.cn (X.Z.); wanlh@ms.giec.ac.cn (L.W.) \\ 2 CAS Key Laboratory of Gas Hydrate, Guangzhou 510640, China \\ 3 Guangdong Provincial Key Laboratory of New and Renewable Energy Research and Development, \\ Guangzhou 510640, China \\ 4 State Key Laboratory of Natural Gas Hydrate, Beijing 100028, China \\ * Correspondence: liangdq@ms.giec.ac.cn; Tel./Fax: +86-20-87057669
}

Received: 30 July 2020; Accepted: 28 August 2020; Published: 2 September 2020

\begin{abstract}
Coal combustion flue gas contains $\mathrm{CO}_{2}$, a greenhouse gas and driver of climate change. Therefore, $\mathrm{CO}_{2}$ separation and removal is necessary. Fortunately, $5 \mathrm{~A}$ zeolites are highly porous and can be used as $\mathrm{CO}_{2}$ adsorbent. In addition, they act as nuclei for hydrate formation. In this work, a composite technology, based on the physical adsorption of $\mathrm{CO}_{2}$ by $5 \mathrm{~A}$ zeolite and hydrate-based gas separation, was used to separate $\mathrm{CO}_{2} / \mathrm{N}_{2}$ gas mixtures. The influence of water content, temperature, pressure, and particle size on gas adsorption and $\mathrm{CO}_{2}$ separation was studied, revealing that the $\mathrm{CO}_{2}$ separation ability of zeolite particles sized 150-180 $\mu \mathrm{m}$ was better than that of those sized 380-830 $\mu \mathrm{m}$ at $271.2 \mathrm{~K}$ and $273.2 \mathrm{~K}$. When the zeolite particles were 150-180 $\mu \mathrm{m}$ (type-B zeolite) with a water content of $35.3 \%$, the gas consumption per mole of water $\left(n_{g a s} / n_{\mathrm{H}_{2} \mathrm{O}}\right)$ reached the maximum, 0.048 , and the $\mathrm{CO}_{2}$ separation ratio reached $14.30 \%$. The $\mathrm{CO}_{2}$ molar concentration in the remaining gas phase $\left(x_{\mathrm{CO}_{2}}^{g a s}\right)$ was lowest at $271.2 \mathrm{~K}$ in the type-B zeolite system with a water content of $47.62 \%$. Raman analysis revealed that $\mathrm{CO}_{2}$ preferentially occupied the small hydrate cages and there was a competitive relationship between $\mathrm{N}_{2}$ and $\mathrm{CO}_{2}$.
\end{abstract}

Keywords: hydrate; 5A zeolite; flue gas; $\mathrm{CO}_{2}$ separation

\section{Introduction}

Various greenhouse gases, emitted by human activities, cause global warming, which continues to worsen. $\mathrm{CO}_{2}$ is the largest contributor to the greenhouse effect [1-3]. Currently, the $\mathrm{CO}_{2}$ emissions of coal-fired power plants account for $40 \%$ of total greenhouse gas emissions. Therefore, decreasing the $\mathrm{CO}_{2}$ emissions in the flue gas of power plants is critical to achieving $\mathrm{CO}_{2}$ emission reduction goals. Depending on the type of power plant, there are three main technologies for decreasing $\mathrm{CO}_{2}$ emissions: pre-combustion capture, oxy-fuel combustion, and post-combustion capture [4-6]. However, based on the advantages and disadvantages of these three technologies, the most widely used, at present, is post-combustion capture. Post-combustion capture refers to the capture and separation of $\mathrm{CO}_{2}$ after coal has been burned. The main components of the flue gas are $\mathrm{CO}_{2}$ and $\mathrm{N}_{2}$. As the concentration of $\mathrm{N}_{2}$ in the air is relatively high, the partial pressure of $\mathrm{CO}_{2}$ in the flue gas is relatively low.

The methods of $\mathrm{CO}_{2}$ separation, include membrane separation, low temperature distillation, chemisorption, and physical adsorption separation $[7,8]$. Among them, adsorption by porous media and gas separation have become hot topics of research in recent years [9-12]. Common adsorbents include metal-organic frameworks (MOFs) [13], zeolites [14], and silica gel [15]. The physical adsorption 
method is generally suitable for $\mathrm{CO}_{2}$ separation at high pressures, in which the $\mathrm{CO}_{2}$ and $\mathrm{CH}_{4}$ separation coefficients of MOFs are better. In addition, the separation coefficient of medium-pore zeolite molecular sieve (SBA-15) is low, whereas the microporous zeolites (such as 5A zeolite and 13X zeolite) have high separation factors [16].

Zeolites are essentially crystalline silicates or aluminosilicates, composed of silicon-oxygen tetrahedrons or silicon-aluminum tetrahedrons, connected by oxygen bridge bonds. Zeolites have a uniform pore size and show a sieving effect on molecules less than, or equal to, the pore size. Two of the commonly used zeolites for gas separation are $5 \mathrm{~A}$ and $13 \mathrm{X}$ zeolites $[17,18]$. As the pore size of $5 \mathrm{~A}$ zeolite is similar to the size of $\mathrm{CO}_{2}$, it is often used for $\mathrm{CO}_{2}$ separation from mixed gases. Saha et al. [13] studied the adsorption capacity of three porous materials, MOF-5, MOF-177, and 5A zeolite, for $\mathrm{CO}_{2}, \mathrm{CH}_{4}, \mathrm{~N}_{2} \mathrm{O}$, and $\mathrm{N}_{2}$, and found that $5 \mathrm{~A}$ zeolite shows better $\mathrm{CO}_{2}$ separation from air and $\mathrm{CH}_{4} / \mathrm{CO}_{2}$ gas mixtures than MOF- 5 and MOF-177. Meanwhile, they also found that $5 \mathrm{~A}$ zeolite can be used for $\mathrm{CO}_{2} / \mathrm{N}_{2}$ and $\mathrm{CO}_{2} / \mathrm{CH}_{4}$ separation but not for $\mathrm{CH}_{4} / \mathrm{N}_{2}$ separation [16,17]. However, physical adsorption requires a large amount of adsorbent, as well as frequent adsorption and desorption. Therefore, the $\mathrm{CO}_{2}$ separation capacity of physical adsorption methods alone is limited.

In recent years, hydrate-based gas separation (HBGS) technology has gained increasing attention as a new adsorption technology [19-21]. Hydrates are special ice-like non-crystalline cage compounds that form under high pressures and low temperatures [22]. Hydrates have different phase equilibrium conditions for different guest molecules. Therefore, gases can be separated by controlling the hydrate formation conditions [23]. However, the formation of hydrates requires high pressures and low temperatures, and the formation rate is relatively slow without an accelerator. Therefore, additives are often used to accelerate the hydrate formation rate [24-26]. The pore structure of 5A zeolite can provide nucleation points for hydrate crystals, thereby, promoting the hydrate formation [27]. At the same time, $5 \mathrm{~A}$ zeolite is also a suitable physical adsorbent for $\mathrm{CO}_{2}$ separation.

Therefore, in this study, considering the pore characteristics of the $5 \mathrm{~A}$ zeolite and the high gas storage capacity of hydrates, both $5 \mathrm{~A}$ zeolite and hydrates were used for $\mathrm{CO}_{2}$ separation from synthesized flue gas $\left(\mathrm{CO}_{2} / \mathrm{N}_{2}\right)$. The $5 \mathrm{~A}$ zeolite has a dual role, acting as both gas adsorbent and kinetic additive for hydrate formation. In addition, the hydrate formation kinetics and $\mathrm{CO}_{2}$ separation in different particle size $5 \mathrm{~A}$ zeolite systems with different water contents under constant pressure and temperatures were studied. Furthermore, the hydrates were sampled and tested by Raman spectroscopy to reveal the interactions between $\mathrm{CO}_{2}$ and $\mathrm{N}_{2}$ in the hydrate cages. The experimental results provide new ideas, and basic theoretical data for $\mathrm{CO}_{2}$ separation from flue gas, using HBGS technology.

\section{Experimental}

\subsection{Experimental Apparatus and Materials}

A schematic of the experimental device for the hydrate reaction is shown in Figure 1. The apparatus comprises a reaction vessel, a buffer tank, an evacuation system, a thermostatic bath, a temperature and pressure monitoring system, a gas chromatography (GC) detection system, and a data acquisition system. The main piece of equipment is the high-pressure reactor vessel with an internal volume of $98 \mathrm{~mL}$ and a buffer tank with an internal volume of $306 \mathrm{~mL}$. The temperature and pressure in reactor vessel and buffer tank were monitored, using a temperature sensor and pressure sensor. The range of the sensor was $223.15-373.15 \mathrm{~K}$ with an accuracy of $\pm 0.1 \mathrm{~K}$. The range of the pressure sensor was 0-20 MPa with an accuracy of $\pm 0.01 \mathrm{MPa}$. Both, the high-pressure reaction vessel and the buffer tank were placed in a thermostatic water bath. The thermostatic control system was a THD-2030 water bath, and the bath was filled with aqueous ethylene glycol solution. Ethylene glycol was provided by Guangzhou Chemical Reagent Factory and had a purity of $>95 \%$. In the experiment, the pressure $(P)$ and temperature $(T)$ data were collected every $10 \mathrm{~s}$ by an Agilent 34970A acquisition system provided by Agilent Technologies Co., Ltd., Santa Clara, CA, USA. 


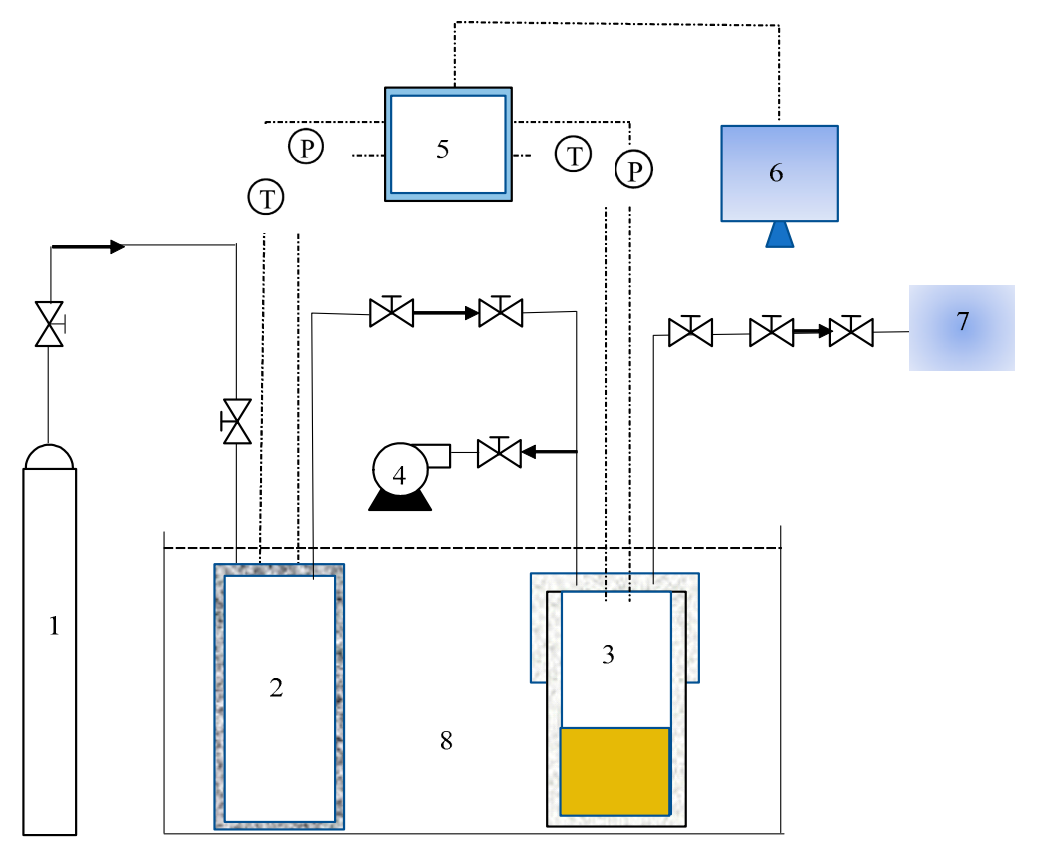

Figure 1. Schematic diagram of hydrate formation experimental reaction device. 1. Gas cylinder, 2. buffer tank, 3. high-pressure reactor vessel, 4. vacuum pump, 5. data acquisition system, 6. computer, 7. gas chromatograph, and 8 . thermostatic bath.

The gas mixture $\left(\mathrm{CO}_{2} / \mathrm{N}_{2}=20 / 80\right)$ was purchased from the Guangzhou Puyuan gas plant in China. The $\mathrm{CO}_{2}$ and $\mathrm{N}_{2}$ used were ultrapure gases having concentrations of $99.9 \%$. The $5 \mathrm{~A}$ zeolite used in the experiment was sieved and classified as type A, having a diameter distribution of $380-830 \mu \mathrm{m}$, and type B, having a diameter distribution of 150-180 $\mu \mathrm{m}$. The 5A zeolite was purchased from Macklin Co., Ltd., Shanghai, China. Deionized water was purchased from Guangzhou Chemical Reagent Factory. The specifications and sources of the experimental devices are shown in Table 1.

Table 1. Experimental devices and specifications.

\begin{tabular}{ccc}
\hline Items & Specification & Uncertainties \\
\hline Temperature sensors & PT-100/Beijing West Air Technology Co., Ltd., Beijing, China & $\pm 0.1 \mathrm{~K}$ \\
Pressure sensor & CYB-20S/Beijing West Air Technology Co., Ltd., Beijing, China & $\pm 0.1 \mathrm{MPa}$ \\
Data acquisition system & Agilent 34970A/Agilent Technologies Co., Ltd., Santa Clara, CA, USA & - \\
Gas chromatography & FL9790/Zhejiang Fuli Analytical Instrument Co., Ltd., Beijing, China & $\pm 0.1 \%$ \\
Constant temperature water bath & THD-2030/Ningbo Tianheng Instrument Factory, Ningbo, China & $\pm 0.1 \mathrm{~K}$ \\
\hline
\end{tabular}

\subsection{Experimental Procedures}

First, $35 \mathrm{~mL}$ of zeolite and an appropriate amount of deionized water were added to the clean reaction vessel. The reaction vessel was sealed and placed in the water bath. Then, gas was charged into the buffer tank slowly after the entire experimental system had been evacuated by a vacuum pump. When the pressure reached $8.50 \pm 0.1 \mathrm{MPa}$, the gas cylinder outlet valve and the buffer tank inlet valve were shut off. Then, the water bath was turned on and the temperature was set to a constant value. Next, the reactor feed was set to the determined pressure, and the gas outlet valve of the buffer tank and the inlet valve of the reactor were closed. After the hydrate reaction had started, the temperature and pressure in the reactor vessel were recorded and monitored by the data acquisition system every $10 \mathrm{~s}$. The hydrate formation reaction was considered complete when the pressure drop of the reactor vessel in $2 \mathrm{~h}$ was less than $0.01 \mathrm{MPa}$. During the experiment, the gas was sampled several times for GC analysis, and the gas composition was analyzed in triplicate. 


\subsection{Microscopic Analysis of Hydrate Samples}

Low-temperature Raman spectroscopy was used for the microscopic analysis of the hydrate samples. Before the tests, the hydrate samples were ground and crushed into fine powder in liquid nitrogen, and then sealed and stored in liquid nitrogen. The Raman analysis was carried out with a confocal Raman spectrometer (Horiba, LabRAM HR, Kyoto, Japan) equipped with a multichannel air-cooled charge-coupled device (CCD) detector and an $\mathrm{Ar}^{+}$laser operating at $532 \mathrm{~nm}$ with a maximum power of $50 \mathrm{~mW}$. Details have been reported previously [28]. The Raman analysis of the hydrate samples was carried out at $180 \mathrm{~K}$. The in situ Raman measurement of hydrate dissociation was carried at $200 \mathrm{~K}$.

\section{Results and Discussion}

The experiments were carried on with two different particle size distributions (type A: 380-830 and type B: $150-180 \mu \mathrm{m}$ ) and four water contents (35.3 wt. $\%, 42.11 \mathrm{wt} . \%, 47.62 \mathrm{wt} . \%$, and $52.17 \mathrm{wt} . \%$, reported as simple percentages, hereafter) to study the hydrate formation kinetics and evaluate the $\mathrm{CO}_{2}$ separation effect under different temperature and pressure conditions. The experimental conditions and results are summarized in Table 2. The initial gas pressure was $8.5 \mathrm{MPa}$.

Table 2. Experimental conditions and results of hydrate based gas separation of $\mathrm{CO}_{2} / \mathrm{N}_{2}$ with $5 \mathrm{~A}$ zeolite.

\begin{tabular}{|c|c|c|c|c|c|c|}
\hline Experiments No. & Zeolite & Temperature/K & Water Content/(wt.\%) & $n_{\text {gas }} / n_{\mathrm{H}_{2} \mathrm{O}}$ & $x_{\mathrm{CO}_{2}}^{\text {gas }}$ & $S_{\mathrm{CO}_{2} / \%}$ \\
\hline 1 & \multirow{8}{*}{$\begin{array}{c}\text { Type A: } \\
380-830 \mu \mathrm{m}\end{array}$} & \multirow{4}{*}{273.2} & 35.30 & 0.017 & 0.129 & 9.65 \\
\hline 2 & & & 42.11 & 0.009 & 0.119 & 10.59 \\
\hline 3 & & & 47.62 & 0.013 & 0.113 & 11.77 \\
\hline 4 & & & 52.17 & 0.013 & 0.099 & 13.60 \\
\hline 5 & & \multirow{4}{*}{271.2} & 35.30 & 0.022 & 0.088 & 14.71 \\
\hline 6 & & & 42.11 & 0.025 & 0.081 & 15.80 \\
\hline 7 & & & 47.62 & 0.010 & 0.091 & 13.72 \\
\hline 8 & & & 52.17 & 0.009 & 0.070 & 16.70 \\
\hline 9 & \multirow{8}{*}{$\begin{array}{c}\text { Type B: } \\
150-180 \mu \mathrm{m}\end{array}$} & \multirow{4}{*}{273.2} & 35.30 & 0.028 & 0.116 & 11.60 \\
\hline 10 & & & 42.11 & 0.023 & 0.102 & 13.27 \\
\hline 11 & & & 47.62 & 0.016 & 0.107 & 12.62 \\
\hline 12 & & & 52.17 & 0.010 & 0.107 & 12.43 \\
\hline 13 & & \multirow{4}{*}{271.2} & 35.30 & 0.048 & 0.098 & 14.30 \\
\hline 14 & & & 42.11 & 0.042 & 0.085 & 16.02 \\
\hline 15 & & & 47.62 & 0.030 & 0.062 & 18.34 \\
\hline 16 & & & 52.17 & 0.019 & 0.068 & 17.54 \\
\hline
\end{tabular}

The gas consumption during hydrate formation at time $t$ during the experiment is given by Equation (1):

$$
\Delta\left(n_{r}\right)_{t}=n_{r, 1}-n_{r, t}=\frac{P_{r, 1} V_{g a s}}{Z_{r, 1} R T_{r, 1}}-\frac{P_{r,} V_{g a s}}{Z_{r, t} R T_{, t}}
$$

Here, $n_{r, 1}$ is the gas amount in the reaction vessel at the initial time (mol), $n_{r, t}$ is the gas amount in the reaction vessel at time $t(\mathrm{~mol})$, and $Z$ is the compression factor calculated using Pitzer's correlation [29].

The gas consumption per unit mole of water at time $t\left(\Delta\left(n_{n o r m}\right)_{t}\right)$ can be calculated using Equation (2):

$$
\Delta\left(n_{\text {norm }}\right)_{t}=\frac{\Delta\left(n_{r}\right)_{t}}{n_{H 2 O}}
$$


The $\mathrm{CO}_{2}$ separation ratio $\left(\mathrm{S}_{\mathrm{CO}_{2}}\right)$ for binary gas mixture mixtures is defined by Equation (3):

$$
S_{\mathrm{CO}_{2}}=\frac{n_{\mathrm{CO}_{2}}^{\mathrm{H}}}{n_{\mathrm{CO}_{2}}^{\text {feed }}} \times 100 \% .
$$

Here, $n_{\mathrm{CO}_{2}}^{\mathrm{H}}$ is the amount of $\mathrm{CO}_{2}$ in the hydrate $(\mathrm{mol})$, and $n_{\mathrm{CO}_{2}}^{\text {feed }}$ is the amount of $\mathrm{CO}_{2}$ in the initial feed gas (mol).

$x_{\mathrm{CO}_{2}}^{\text {gas }}$ is the molar concentration of $\mathrm{CO}_{2}$ in the remaining gas phase, which can be calculated using Equation (4):

$$
x_{\mathrm{CO}_{2}}^{g a s}=\frac{n_{\mathrm{CO}_{2}}^{g a s}}{n_{\mathrm{CO}_{2}}^{g a s}+n_{N_{2}}^{g a s}} .
$$

Here, $n_{\mathrm{CO}_{2}}^{\text {gas }}$ and $n_{\mathrm{N}_{2}}^{\text {gas }}$ are the amount of $\mathrm{CO}_{2}$ and $\mathrm{N}_{2}$ in the remaining gas phase, respectively (mol). The pressure curves during hydrate formation under different experimental conditions are shown in Figure 2. As shown in Figure 2a, in the first $300 \mathrm{~min}$, the pressure drop and gas consumption increased as the water content increased from $35.3 \%$ to $52.17 \%$ for the type-A zeolite at $273.2 \mathrm{~K}$. In addition, the pressure drop in the initial $50 \mathrm{~min}$ accounts for more than $80 \%$ of the total pressure drop. As shown in Figure 2b, when the temperature was reduced to $271.2 \mathrm{~K}$, a large pressure drop occurred because of the "secondary formation" of hydrates, but the other conditions remained unchanged. The pressure drop was largest with the type-A zeolite at $271.2 \mathrm{~K}$ having a water content of $35.30 \%$, but it increased as the water contents increased from $42.11 \%$ to $47.62 \%$ and $52.17 \%$. For type-B zeolite (i.e., smaller particles), the gas pressure drop was the largest at water contents of $42.11 \%$ and $52.17 \%$ at $273.2 \mathrm{~K}$, and $271.2 \mathrm{~K}$, respectively, as shown in Figure $2 \mathrm{c}$,d. The pressure drop increased with the increase in water content in the initial $300 \mathrm{~min}$ for the type-B zeolite at $271.2 \mathrm{~K}$ (Figure 2d). In general, in the type-B zeolite system, the magnitude of the gas pressure drop and its trend with water contents at 271.2 K changed little, compared with those of the other systems. In addition, the trends in the pressure drop with different water contents were also different when the other experimental conditions were fixed, as shown in Figure $2 b$,c. It was found that, under certain experimental conditions, the hydrate reaction proceeded in two stages. As shown in Figure 2b,c, when the water contents were 35.30\% and $42.11 \%$, the gas phase pressure dropped rapidly in the initial stage of the reaction. Then, there was a plateau stage where the pressure drop was very slight, that means hydrate formation rate was low at this stage, and then, it dropped sharply again until the end of the reaction. At the same time, under these conditions, the total decrease in gas pressure was the greatest.

To characterize the hydrate formation kinetics clearly, the gas consumption per unit mole of water $\left(n_{\text {gas }} / n_{\mathrm{H}_{2} \mathrm{O}}\right)$ under different conditions was calculated, and the results are listed in Table 2 and shown in Figure 3. The results obtained in this work are the average of three sets of repeated experiments. To ensure the reliability of the results, error bars are given in Figure 3. The error bas are the standard deviation that determined from the three repeated experimental data. Combined with the pressure variation in Figure 2, we determined that the $n_{g a s} / n_{\mathrm{H}_{2} \mathrm{O}}$ values for four gas compositions for the type- $\mathrm{B}$ zeolite at $271.2 \mathrm{~K}$ were larger than those under other experimental conditions. In particular, the maximum $n_{g a s} / n_{\mathrm{H}_{2} \mathrm{O}}$ was 0.048 at a water content of $35.3 \%$. Overall, $n_{g a s} / n_{\mathrm{H}_{2} \mathrm{O}}$ for the type-B zeolite was greater than that of the type-A zeolite under these experimental conditions. Therefore, smaller zeolite particles are more conducive to the formation of hydrates, thereby, increasing the total gas consumption. 


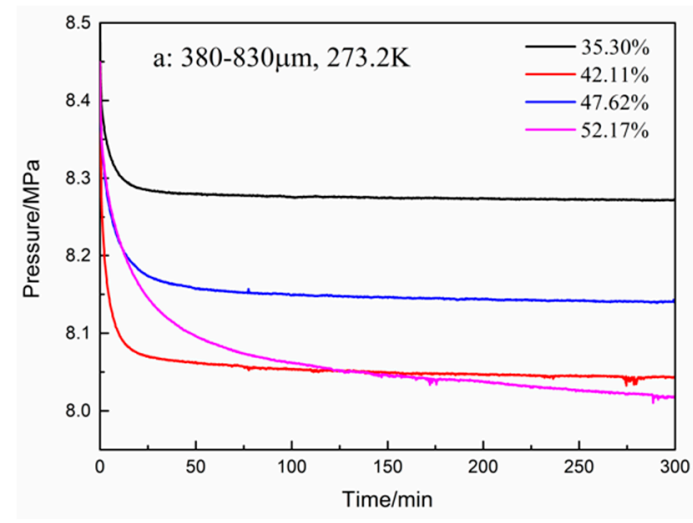

(a)

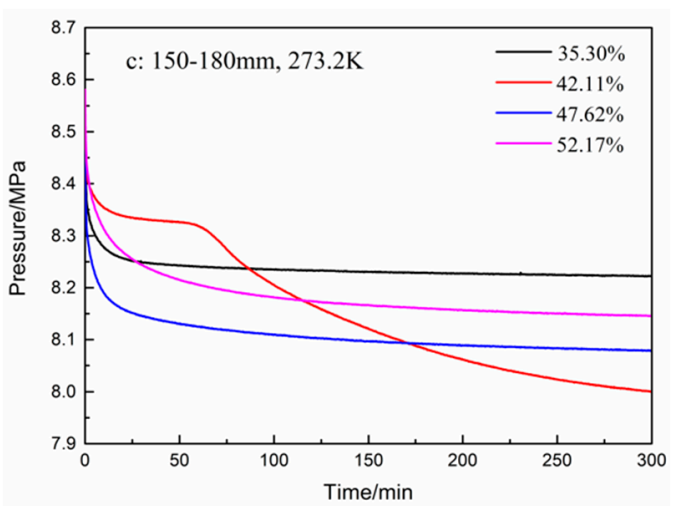

(c)

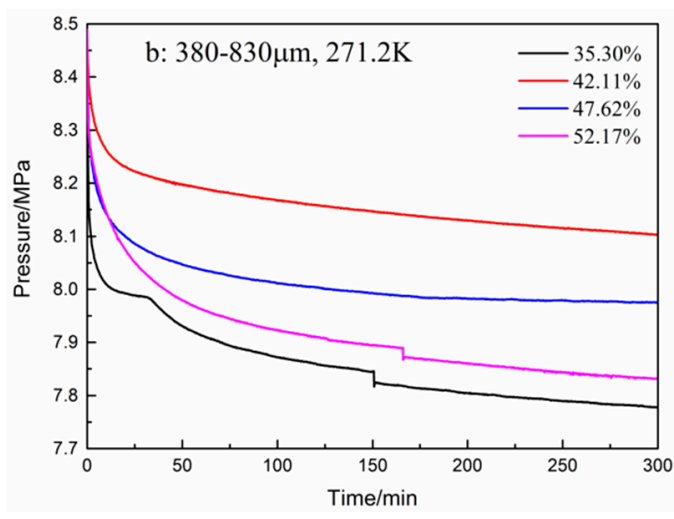

(b)

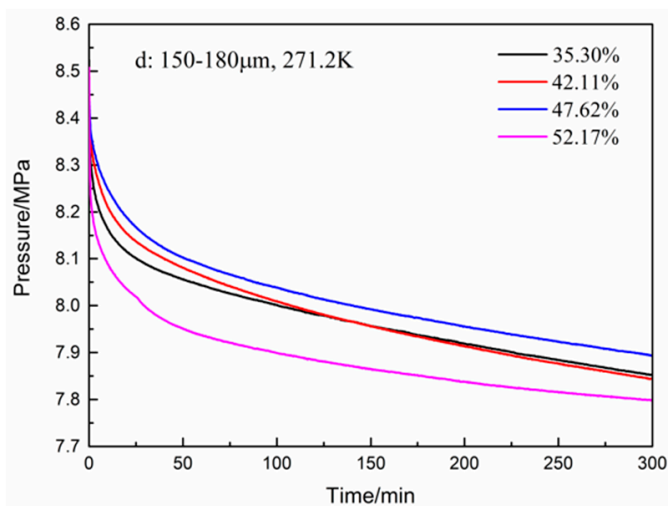

(d)

Figure 2. Pressure drops for zeolites having different water contents at various temperatures.

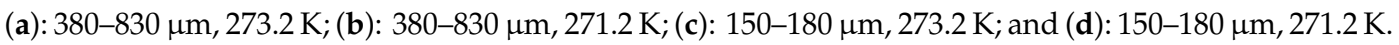

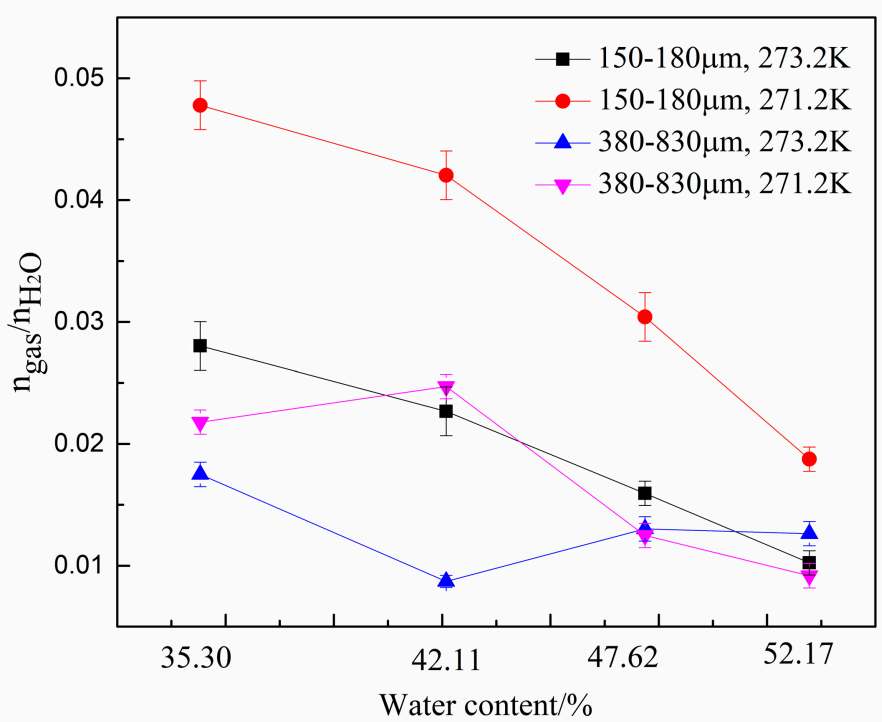

Figure 3. Gas consumption per unit mole of water $\left(n_{g a s} / n_{\mathrm{H}_{2} \mathrm{O}}\right)$ under different experimental conditions.

Meanwhile, for the type-B zeolite system, $n_{g a s} / n_{\mathrm{H}_{2} \mathrm{O}}$ decreased with increase in water content because, for mixed zeolite and water systems, the total gas consumption consists of two parts: The gas adsorbed by the pores of the zeolite and the gas stored in the hydrate cage structure. The effective 
aperture of $5 \mathrm{~A}$ zeolites was about $0.5 \mathrm{~nm}$. The molecule diameters of $\mathrm{CO}_{2}$ and $\mathrm{N}_{2}$ are $0.51 \mathrm{~nm}$, and $0.41 \mathrm{~nm}$, respectively. As the water content increased, the water occupied more zeolite pores, thereby, reducing the adsorption capacity of the zeolite itself and resulting in a decrease of the total gas consumption. Furthermore, because the gas storage capacity of the hydrate and the adsorption capacity of the zeolite are not equal, according to the definition of $n_{\text {gas }} / n_{\mathrm{H}_{2} \mathrm{O}}$, it decreases as the water content increases.

However, for type-A zeolite system, the relationship between $n_{g a s} / n_{\mathrm{H}_{2} \mathrm{O}}$ and water content was not linear. Therefore, in combination with the pressure change curve shown in Figure 2, we determined that there is an optimal water content for each zeolite system at which the formation of hydrates is most favorable.

In addition to the total gas consumption and unit consumption, the $\mathrm{CO}_{2}$ separation effect is a focus of this work. The changes in the $\mathrm{CO}_{2}$ and $\mathrm{N}_{2}$ molar ratio during hydrate formation are shown in Figures 4 and 5. A total of five samples were taken from the gas phase in the experiment. As shown in Figure 4, the $\mathrm{CO}_{2}$ molar ratio decreased sharply in the first $500 \mathrm{~min}$. The $\mathrm{N}_{2}$ molar ratio increased correspondingly. Subsequently, the $\mathrm{CO}_{2}$ molar ratio continued to decrease slowly until the end of the reaction. However, when the water content was $35.30 \%$ in the type- $\mathrm{B}$ zeolite system, the $\mathrm{CO}_{2}$ gas molar ratio rose slightly before the end of the reaction, but, despite this, the $\mathrm{CO}_{2}$ gas molar ratio was still minimized at the end of the reaction. Correspondingly, the $\mathrm{N}_{2}$ molar ratio shows a similar trend.

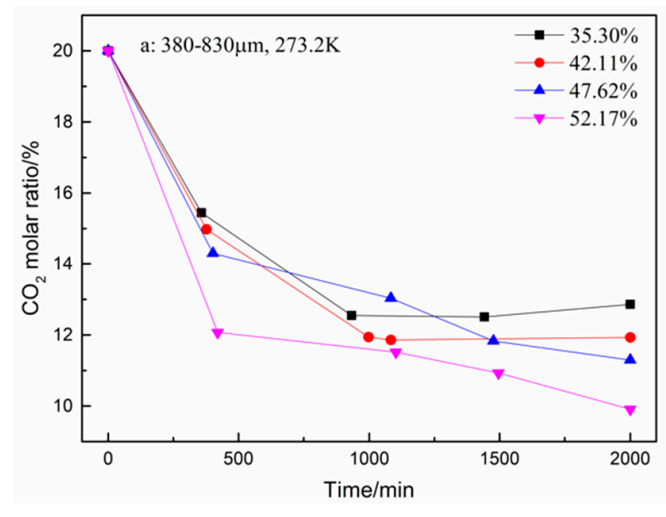

(a)

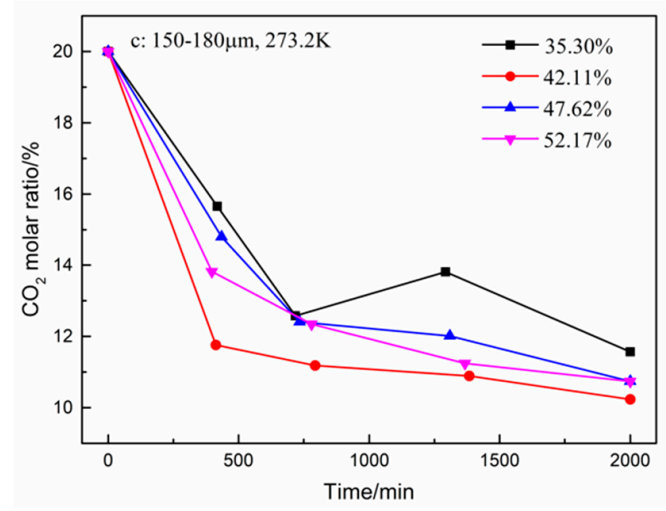

(c)

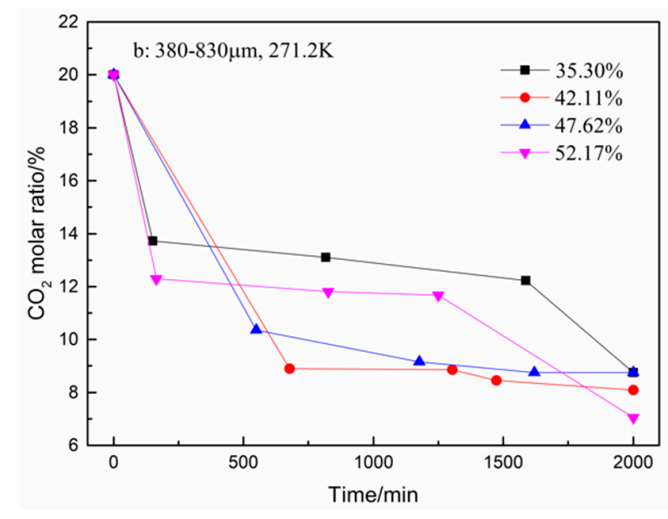

(b)

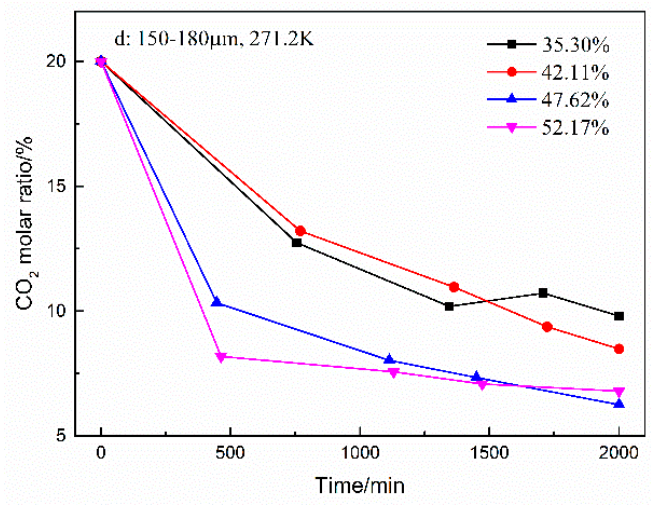

(d)

Figure 4. $\mathrm{CO}_{2}$ molar ratio in the gas phase after hydrate formation under different conditions.

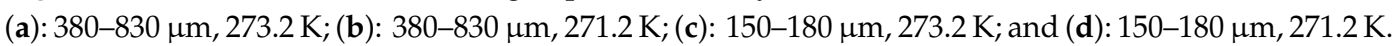

To characterize the $\mathrm{CO}_{2}$ separation effect, the $\mathrm{CO}_{2}$ molar concentration in the remaining gas phase $\left(x_{\mathrm{CO}_{2}}^{g a s}\right)$ in zeolites with different water content are compared in Figure 6. As shown in the 
figure, for the same zeolite particle size, $x_{\mathrm{CO}_{2}}^{\text {gas }}$ was lower at $271.2 \mathrm{~K}$ than that at $273.2 \mathrm{~K}$, indicating that lower temperatures enhance the $\mathrm{CO}_{2}$ gas separation effect. Under same experimental conditions, $x_{\mathrm{CO}_{2}}^{g a s}$ decreased when the water content was increased from $35.3 \%$ to $42.11 \%$. However, when the water content was greater than $42.11 \%, x_{\mathrm{CO}_{2}}^{g a s}$ was not only affected by the water content but also affected by the temperature and zeolite particle size. When the water content increased from $47.62 \%$ to $52.17 \%$, $x_{\mathrm{CO}_{2}}^{g a s}$ decreased in the system with type-A zeolite and increased in system with type B zeolite. Overall, $x_{\mathrm{CO}_{2}}^{\text {gas }}$ was lowest at $271.2 \mathrm{~K}$ in the system with type-B zeolite having a water content of $47.62 \%$.

The $\mathrm{CO}_{2}$ separation ratio also reflects the capacity of hydrates to capture $\mathrm{CO}_{2}$. To compare the gas separation abilities of various systems, the $\mathrm{CO}_{2}$ separation ratios are compared in Figure 7 . The error bars are given in Figures 6 and 7 too. As for the data in Figure 6, the $\mathrm{CO}_{2}$ separation ratio was largest at $271.2 \mathrm{~K}$ in the type-B zeolite system having a water content of $47.62 \%$. Moreover, the relationship between the $\mathrm{CO}_{2}$ separation ratio and various experimental conditions was consistent with the trend in $x_{\mathrm{CO}_{2}}^{\text {gas }}$. Therefore, all factors, including zeolite particle size, water contents, and thermodynamic conditions, affect the gas separation ability in the HBGS method and should be evaluated comprehensively. In addition, there are optimal experimental conditions in HBGS where the best $\mathrm{CO}_{2}$ separation effect was observed.

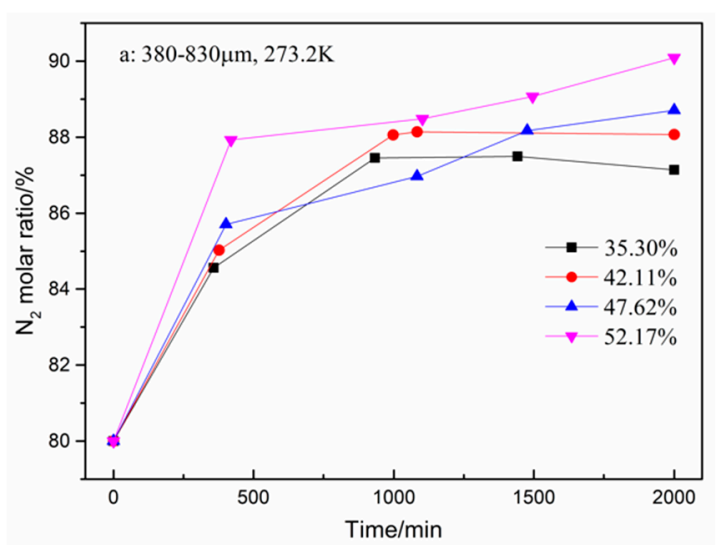

(a)

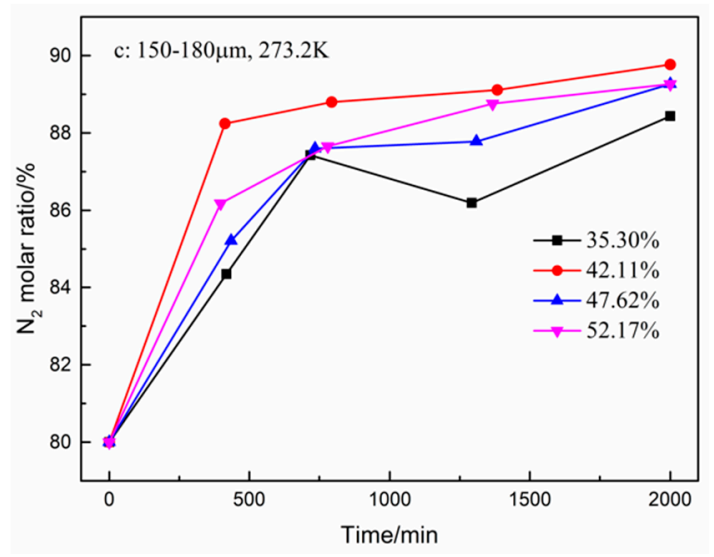

(c)

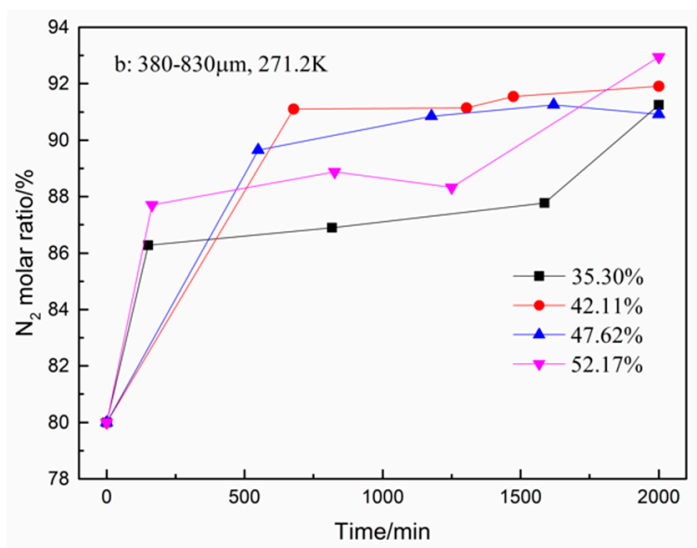

(b)

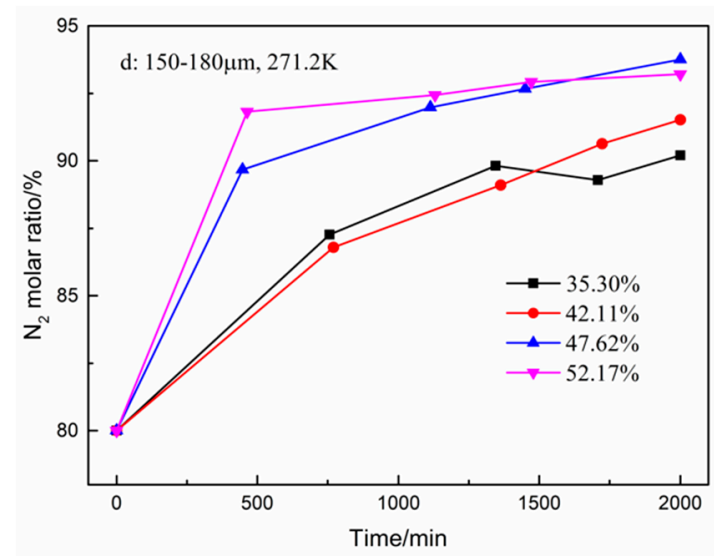

(d)

Figure 5. $\mathrm{N}_{2}$ molar ratio in gas phase after hydrate formation under different conditions. (a): 380-830 $\mu \mathrm{m}$,

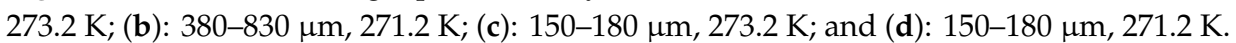




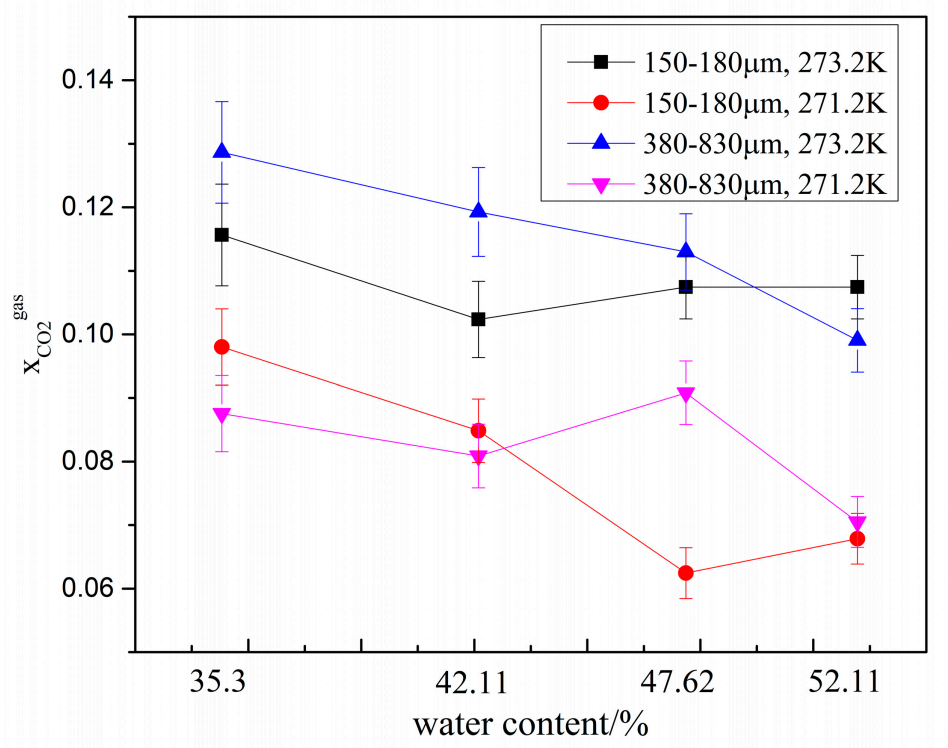

Figure 6. $\mathrm{CO}_{2}$ molar concentration in the remaining gas phase $\left(x_{\mathrm{CO}_{2}}^{g a s}\right)$ in the presence of different amounts of water.

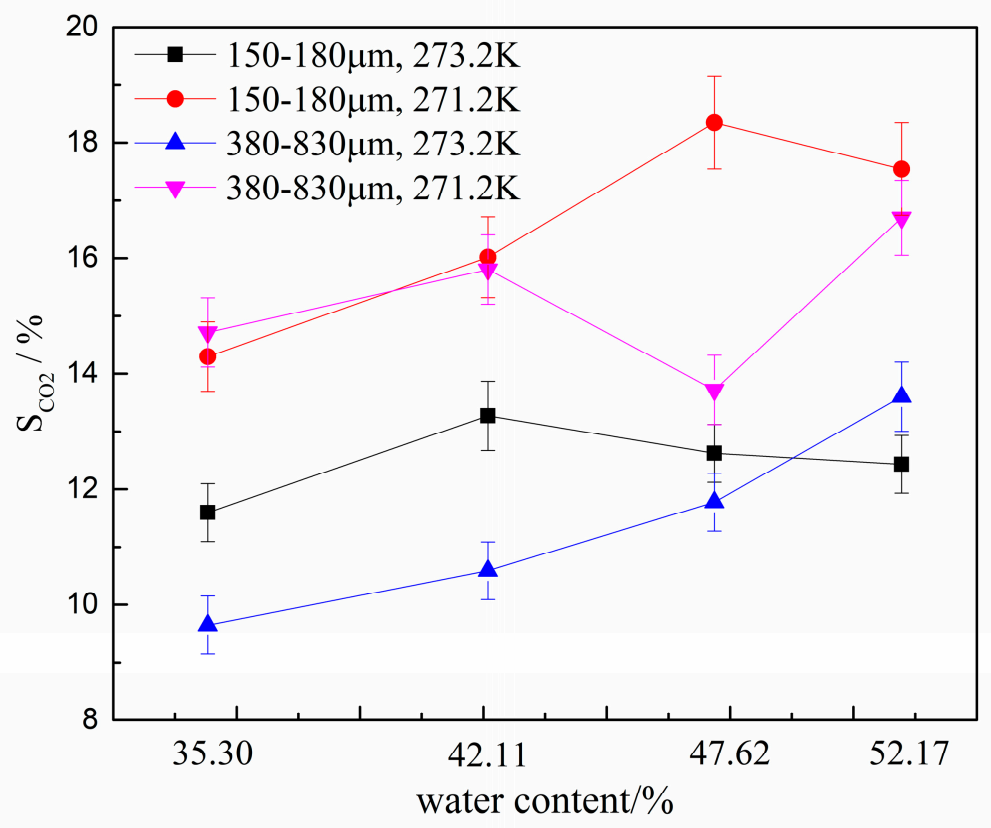

Figure 7. $\mathrm{CO}_{2}$ separation ratios for different water contents.

The molecular sizes of $\mathrm{CO}_{2}$ and $\mathrm{N}_{2}$ are different, so $\mathrm{CO}_{2}$ form typical structure I (sI) hydrates, and $\mathrm{N}_{2}$ form typical structure II (sII) hydrates. The Raman shifts of pure $\mathrm{CO}_{2}$ hydrates occur at about 1276.6 and $1381.1 \mathrm{~cm}^{-1}$, whereas the Raman shift of $\mathrm{N}_{2}$ is about $2324.5 \mathrm{~cm}^{-1}$ [30]. For hydrates with multicomponent guest molecules, a different hydrate structure can form, and the Raman displacement will be correspondingly affected. Hydrates formed of binary gas mixture of $\mathrm{CO}_{2} / \mathrm{N}_{2}\left(\mathrm{CO}_{2}\right.$ gas molar ratio $<1 \%$ ) can be structure II (sII) hydrate. However, the sI hydrate forms if the $\mathrm{CO}_{2}$ molar ratio is increased to $20 \%$ [22]. Meanwhile, the diameter of $5 \mathrm{~A}$ zeolite is similar to that of the hydrate cage structure. Hydrate samples formed under different conditions were analyzed by Raman spectroscopy, in order to investigate whether the $5 \mathrm{~A}$ zeolite affects the structure of the hydrates and the distribution of $\mathrm{CO}_{2}$ and $\mathrm{N}_{2}$ contained within. The Raman spectra of hydrate samples in type-A and B zeolite systems with different water contents at $271.2 \mathrm{~K}$ are shown in Figure 8. 
The Raman spectra in Figure 8 contain two bands $1278 \mathrm{~cm}^{-1}$ and $1375 \mathrm{~cm}^{-1}$. These are the double peaks of the $\mathrm{C}-\mathrm{O}$ Fermi resonance, indicating that $\mathrm{CO}_{2}$ preferentially occupied the large cages of the sI hydrate, and the $\mathrm{CO}_{2}$ molecules competed with $\mathrm{N}_{2}$ to fill the small cages of the sI hydrate. In addition, the band near $2321 \mathrm{~cm}^{-1}$ is the N-N vibration of $\mathrm{N}_{2}$. Therefore, the hydrates formed under all experimental conditions were sI type, and the zeolite neither participates in the hydrate formation reaction nor influences the hydrate structure.

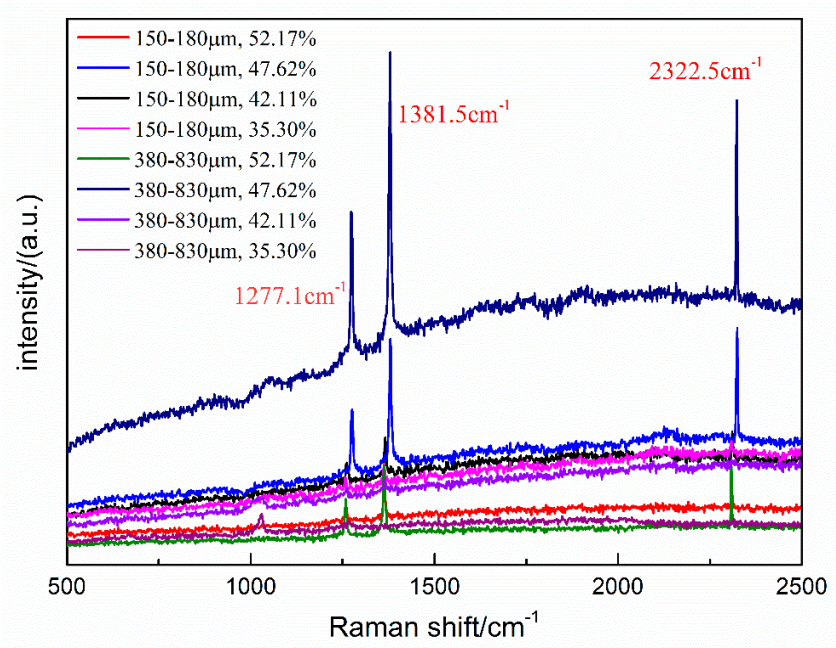

Figure 8. Raman spectra of hydrates formed in zeolite systems with different water contents at $271.2 \mathrm{~K}$.

Finally, to study the decomposition of the hydrate and the escape of $\mathrm{CO}_{2}$ and $\mathrm{N}_{2}$ from the hydrate cage structure, one hydrate sample formed in the type-B zeolite system with $42.11 \%$ water content at $271.2 \mathrm{~K}$ was examined by in situ Raman spectroscopy. The dissociation temperature was determined to be $200 \mathrm{~K}$. As shown in Figure 9, as time progressed, the intensities of the $\mathrm{CO}_{2}$ and $\mathrm{N}_{2}$ bands decreased simultaneously, indicating that the two gases escape from the hydrate cage structure at the same time. Moreover, the decomposition of the hydrate was complete within $60 \mathrm{~min}$.

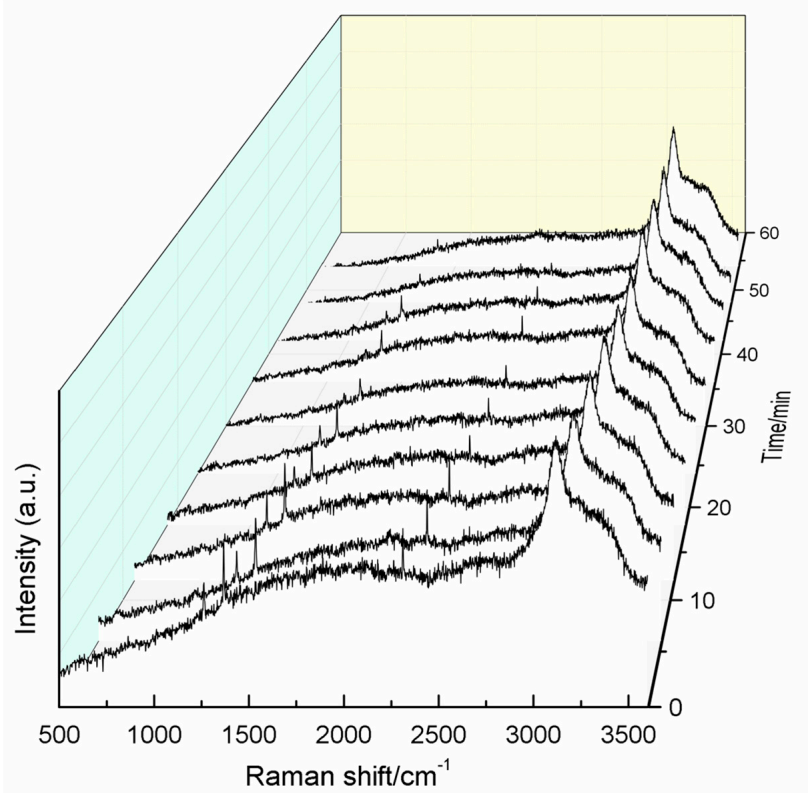

Figure 9. In situ Raman spectra during hydrate decomposition. 


\section{Conclusions}

Hydrate formation in 5A zeolites with different particle size distributions (380-830 and $150-180 \mu \mathrm{m}$ ) was investigated at $273.2 \mathrm{~K}$ and $271.2 \mathrm{~K}$ at $8.5 \mathrm{MPa}$. Four water contents were investigated in the experiments. It was found that, for the same zeolite particle distribution, the $\mathrm{CO}_{2}$ molar concentration in the remaining gas phase $\left(x_{\mathrm{CO}_{2}}^{g a s}\right)$ was lower at $271.2 \mathrm{~K}$ than that at $273.2 \mathrm{~K}$ and lower temperature can improve the separation effect of $\mathrm{CO}_{2}$. On the basis of the results obtained under all experimental conditions, $x_{\mathrm{CO}_{2}}^{g a s}$ was lowest at $271.2 \mathrm{~K}$ in the type-B zeolite $(150-180 \mu \mathrm{m})$ with water content of $47.62 \%$. However, the gas consumption per mole of water $\left(n_{g a s} / n_{\mathrm{H}_{2} \mathrm{O}}\right)$ was maximum in the type-B zeolite $(150-180 \mu \mathrm{m})$ with a water content of $35.3 \%$. Therefore, the zeolite particle distribution, water content, and thermodynamic conditions affect gas separation in the HBGS method and should be evaluated comprehensively, and there are optimal HBGS experimental conditions. In addition, the 5A zeolite does not participate in the hydrate formation reaction and does not influence the structure of the hydrate. When the hydrate decomposed, $\mathrm{CO}_{2}$ and $\mathrm{N}_{2}$ molecules escape from the hydrate structure almost simultaneously.

The results in this work indicated that $5 \mathrm{~A}$ zeolite + water system based on HBGS technology can act as a preferable absorbent for $\mathrm{CO}_{2}$ separation from binary $\mathrm{CO}_{2} / \mathrm{N}_{2}$ gas mixtures. Crucially, the operating conditions should be chosen properly to ensure the best $\mathrm{CO}_{2}$ separation effect and capability. For gases with different components, experimental conditions should be considered and investigated comprehensively to achieve the best separation, which is our goal for future work. Meanwhile, $5 \mathrm{~A}$ zeolite is not suitable for hydrate based gas separation under atmospheric pressure. Further work need to do and find appropriate additives that can reduce the formation conditions of hydrate, promote the formation rate and enhance the gas absorption and separation capabilities.

Author Contributions: Conceptualization, D.L. and X.Z. (Xiaoya Zang); methodology, X.Z. (Xuebing Zhou); investigation, N.Z. and L.W.; writing-review and editing, X.Z. (Xiaoya Zang). All authors have read and agreed to the published version of the manuscript.

Funding: This research was funded by National key research and development plan of China (grant number: 2017YFC0307305), National Natural Science Foundation of China (grant numbers: 51676197), Guangzhou Science and Technology Project (grant number: 201804010411) and Youth Innovation Promotion Association CAS.

Conflicts of Interest: The authors declare no conflict of interest. The funders had no role in the design of the study; in the collection, analyses, or interpretation of data; in the writing of the manuscript, or in the decision to publish the results.

\section{References}

1. Ahmed, M. Introduction to Modern Climate Change. Sci. Total. Environ. 2020, 734, 139397. [CrossRef]

2. Bachmann, T.M. Considering environmental costs of greenhouse gas emissions for setting a $\mathrm{CO}_{2}$ tax: A review. Sci. Total. Environ. 2020, 720, 137524. [CrossRef] [PubMed]

3. Zhao, S.; Pudasainee, D.; Duan, Y.; Gupta, R.; Liu, M.; Lu, J. A review on mercury in coal combustion process: Content and occurrence forms in coal, transformation, sampling methods, emission and control technologies. Prog. Energy Combust. Sci. 2019, 73, 26-64. [CrossRef]

4. Gholami, F.; Tomas, M.; Gholami, Z.; Vakili, M. Technologies for the nitrogen oxides reduction from flue gas: A review. Sci. Total. Environ. 2020, 714, 136712. [CrossRef] [PubMed]

5. Patron, G.D.; Ricardez-Sandoval, L. A robust nonlinear model predictive controller for a post-combustion $\mathrm{CO}_{2}$ capture absorber unit. Fuel 2020, 265, 116932. [CrossRef]

6. Anantharaman, R.; Peters, T.; Xing, W.; Fontaine, M.-L.; Bredesen, R. Dual phase high-temperature membranes for $\mathrm{CO}_{2}$ separation-Performance assessment in post- and pre-combustion processes. Faraday Discuss. 2016, 192, 251-269. [CrossRef]

7. Songolzadeh, M.; Soleimani, M.; Ravanchi, M.T.; Songolzadeh, R. Carbon Dioxide Separation from Flue Gases: A Technological Review Emphasizing Reduction in Greenhouse Gas Emissions. Sci. World J. 2014, 2014, 1-34. [CrossRef]

8. Sumida, K.; Rogow, D.L.; Mason, J.A.; McDonald, T.M.; Bloch, E.D.; Herm, Z.R.; Bae, T.-H.; Long, J.R. Carbon Dioxide Capture in Metal-Organic Frameworks. Chem. Rev. 2012, 112, 724-781. [CrossRef] 
9. Yuan, B.; Wu, X.; Chen, Y.; Huang, J.; Luo, H.; Deng, S. Adsorption of $\mathrm{CO}_{2}, \mathrm{CH}_{4}$, and $\mathrm{N}_{2}$ on Ordered Mesoporous Carbon: Approach for Greenhouse Gases Capture and Biogas Upgrading. Environ. Sci. Technol. 2013, 47, 5474-5480. [CrossRef]

10. Ding, S.; Liu, Y. Adsorption of $\mathrm{CO}_{2}$ from flue gas by novel seaweed-based $\mathrm{KOH}$-activated porous biochars. Fuel 2020, 260, 116382. [CrossRef]

11. Younas, M.; Rezakazemi, M.; Daud, M.; Wazir, M.B.; Ahmad, S.; Ullah, N.; Inamuddin; Ramakrishna, S. Recent progress and remaining challenges in post-combustion $\mathrm{CO}_{2}$ capture using metal-organic frameworks (MOFs). Prog. Energy Combust. Sci. 2020, 80, 100849. [CrossRef]

12. Mukherjee, A.; Okolie, J.A.; Abdelrasoul, A.; Niu, C.H.; Dalai, A.K. Review of post-combustion carbon dioxide capture technologies using activated carbon. J. Environ. Sci. 2019, 83, 46-63. [CrossRef] [PubMed]

13. Saha, D.; Bao, Z.; Jia, F.; Deng, S. Adsorption of $\mathrm{CO}_{2}, \mathrm{CH}_{4}, \mathrm{~N}_{2} \mathrm{O}$, and $\mathrm{N}_{2}$ on MOF-5, MOF-177, and Zeolite 5A. Environ. Sci. Technol. 2010, 44, 1820-1826. [CrossRef] [PubMed]

14. Pour, A.A.; Sharifnia, S.; NeishaboriSalehi, R.; Ghodrati, M. Performance evaluation of clinoptilolite and $13 \mathrm{X}$ zeolites in $\mathrm{CO}_{2}$ separation from $\mathrm{CO}_{2} / \mathrm{CH}_{4}$ mixture. J. Nat. Gas Sci. Eng. 2015, 26, 1246-1253. [CrossRef]

15. Liu, J.; Ding, J.X.; Liang, D.Q. Experimental study on hydrate-based gas separation of mixed $\mathrm{CH}_{4} / \mathrm{CO}_{2}$ using unstable ice in a silica gel bed. Energy 2018, 157, 54-64. [CrossRef]

16. Mofarahi, M.; Gholipour, F. Gas adsorption separation of $\mathrm{CO}_{2} / \mathrm{CH}_{4}$ system using zeolite 5A. Microporous Mesoporous Mater. 2014, 200, 1-10. [CrossRef]

17. Mendes, P.A.P.; Ribeiro, A.M.; Gleichmann, K.; Ferreira, A.F.P.; Rodrigues, A.E. Separation of $\mathrm{CO}_{2} / \mathrm{N}_{2}$ on binderless 5A zeolite. J. CO2 Util. 2017, 20, 224-233. [CrossRef]

18. Bakhtyari, A.; Mofarahi, M. Pure and Binary Adsorption Equilibria of Methane and Nitrogen on Zeolite 5A. J. Chem. Eng. Data 2014, 59, 626-639. [CrossRef]

19. Li, S.; Fan, S.; Wang, J.; Lang, X.; Wang, Y. Clathrate Hydrate Capture of $\mathrm{CO}_{2}$ from Simulated Flue Gas with Cyclopentane/Water Emulsion. Chin. J. Chem. Eng. 2010, 18, 202-206. [CrossRef]

20. Li, L.; Fan, S.; Chen, Q.; Yang, G.; Zhao, J.; Wei, N.; Wen, Y. Simulation of post-combustion $\mathrm{CO}_{2}$ capture process by non-equilibrium stage hydrate-based gas separation technology. Int. J. Greenh. Gas Control. 2018, 79, 25-33. [CrossRef]

21. Kim, S.; Choi, S.-D.; Seo, Y. $\mathrm{CO}_{2}$ capture from flue gas using clathrate formation in the presence of thermodynamic promoters. Energy 2017, 118, 950-956. [CrossRef]

22. Sloan, E.D.; Koh, C. Clathrate Hydrates of Natural Gases; CRC Press: Boca Raton, FL, USA, 2007.

23. Wang, X.; Zhang, F.; Lipiński, W. Research progress and challenges in hydrate-based carbon dioxide capture applications. Appl. Energy 2020, 269, 114928. [CrossRef]

24. Pandey, J.S.; Daas, Y.J.; Von Solms, N. Screening of Amino Acids and Surfactant as Hydrate Promoter for $\mathrm{CO}_{2}$ Capture from Flue Gas. Processes 2020, 8, 124. [CrossRef]

25. Abu Hassan, M.H.; Sher, F.; Zarren, G.; Suleiman, N.; Tahir, A.A.; Snape, C.E. Kinetic and thermodynamic evaluation of effective combined promoters for $\mathrm{CO}_{2}$ hydrate formation. J. Nat. Gas Sci. Eng. 2020, 78, 103313. [CrossRef]

26. Nasir, Q.; Suleman, H.; Elsheikh, Y.A. A review on the role and impact of various additives as promoters/inhibitors for gas hydrate formation. J. Nat. Gas Sci. Eng. 2020, 76, 103211. [CrossRef]

27. Khurana, M.; Yin, Z.; Linga, P. A Review of Clathrate Hydrate Nucleation. ACS Sustain. Chem. Eng. 2017, 5, 11176-11203. [CrossRef]

28. Zhou, X.; Long, Z.; Liang, S.; He, Y.; Yi, L.; Li, D.-L.; Liang, D. In SituRaman Analysis on the Dissociation Behavior of Mixed $\mathrm{CH}_{4}-\mathrm{CO}_{2}$ Hydrates. Energy Fuels 2016, 30, 1279-1286. [CrossRef]

29. Zhong, D.-L.; Li, Z.; Lu, Y.-Y.; Wang, J.-L.; Yan, J.; Qing, S.-L. Investigation of $\mathrm{CO}_{2}$ Capture from a $\mathrm{CO}_{2}+$ $\mathrm{CH}_{4}$ Gas Mixture by Gas Hydrate Formation in the Fixed Bed of a Molecular Sieve. Ind. Eng. Chem. Res. 2016, 55, 7973-7980. [CrossRef]

30. Chazallon, B.; Pirim, C. Selectivity and $\mathrm{CO}_{2}$ capture efficiency in $\mathrm{CO}_{2}-\mathrm{N}_{2}$ clathrate hydrates investigated by in-situ Raman spectroscopy. Chem. Eng. J. 2018, 342, 171-183. [CrossRef]

(C) 2020 by the authors. Licensee MDPI, Basel, Switzerland. This article is an open access article distributed under the terms and conditions of the Creative Commons Attribution (CC BY) license (http://creativecommons.org/licenses/by/4.0/). 